\title{
Population Demography \& Impact of Terrorism in State of Jammu \& Kashmir
}

\author{
Shubham Yadav \\ J.S. University, Shikohabad, India
}

\begin{abstract}
Population demography in the All-Time violence and terrorism suffered but naturally extremely beautiful most northern region of India, the state of Jammu and Kashmir, has always been of interest for researchers in the fields of geography, political science, and sociology. This paper studies the persistence of the effects of terrorist attacks on the population demographics in the state of Jammu and Kashmir in India.
\end{abstract}

The results reveal that the terrorism had a negative and transitory impact on population growth. This is further captured that the incidents of deaths implied more adverse effects on population demography and made it even more uneven in the state.

Key words: $\quad$ Population Demographics; Terrorism; Cross Border Politics

\section{Introduction}

'Jammu and Kashmir' is the northern-most state of India that is highly rich in natural vegetation and water resources but face extreme climate conditions and have been suffering from Communal Terrorism for many decades.

This although is a Muslim majority state but has good population from other religions including Hindu, Sikh, and Buddhism.

Communal Terrorism in past few decades in the state has forced multiple migrations of populations of specific religions and has hereby negatively impacted the sustainable growth of population of different religions in the state. Whereas the overall religious population demographics have not changed significantly but the distribution of the population has been highly impacted.

\section{II.Population Demographics in Jammu and Kashmir}

Jammu and Kashmir state of India is a Muslim majority state although it has good population from communities of Buddhists, Hindus and Sikhs too. The spatial distribution and density of population in the state is highly uneven due to different physical factors.

\section{A. Spatial Demographics of Population}

The spatial distribution and density of population in the state is highly uneven. The state experiences extreme weather conditions in sloppy and fields areas and this further makes the special distribution of the population uneven.
Naturally, the physical factors like climate conditions, terrain, topography, slope, natural vegetation, availability of agriculture resources, drainage soil, transport, roads, and other resources plays decisional roles in distribution of population over any region and due to highly uneven physical factors, the special distribution of human population in the state of Jammu and Kashmir is also uneven.

In general, Jammu plains and the Jhelum floor or the Kashmir Valley serves to about 85 per cent of the total population of the state whereas about 14 per cent of the total population is living in the Kandi that constitute the lower hilly slopes areas and the side valleys in the state within $2,000 \mathrm{~m}$ above the sea level. The remaining about $1 \%$ of the total population of the state is distributed in the areas of high latitudinal zones of the Himalayas, Zanskar, Karakoram Ranges, and Ladakh region.

\section{B. Religious Demographics of Population}

Jammu and Kashmir state of India is a Muslim majority state and about $67 \%$ of the population of the state is Muslim. Further about $97 \%$ of the population of the Kashmir Valley region of the state is Muslim although the state also has good population from communities of Buddhists, Hindus (inclusive of Megh Bhagats) and Sikhs.

In Jammu, Hindus, Muslim, and Sikh populations respectively constitute $65 \%, 31 \%$ and $4 \%$ of the population. Ladakh is a Buddhists majority region who constitute about $46 \%$ of the population whereas the remaining is the Muslims population.

In aggregation, the Muslims constitute $67 \%$ of the population in the state of Jammu and Kashmir whereas $30 \%$ are the 
Hindus, $2 \%$ are the Sikh, whereas the remaining $1 \%$ are the Buddhists population in the state. [7]

\section{Terrorism in J\&K}

According to an official report of Ministry of External Affairs, Govt. of India, since 1990, the State of Jammu and Kashmir has been the main area of actions of Terrorism activities sponsored by external sources. These terrorism activities have cost many thousand lives (about 27,000 till 2001 from 1990) in the state. The causalities include defense personnel as well as civilians. [10]

According to the reports, the terrorist violence caused extensive damage to private and public property, with large number of people, particularly minority Hindus, being forced to migrate from the Valley. A political scientist Alexander Evans stated that approximately 150,000 to 160,000 Kashmiri Pandits) that constituted about $95 \%$ of the total Hindu population of the state left the Kashmir Valley in 1990 as militancy engulfed the state. Additionally, about 300,000 Kashmiri Pandits from the state have been internally displaced due to the ongoing violence, as estimated by the Central Intelligence Agency in one of their report. [10]

\section{Impact of Terrorism on Population Demographics in J\&K}

According to 1961 Census that was the first in the state after independence and partition of India, Muslims population constituted 68.3 per cent of the state population whereas Hindus population constituted 28.45 per cent of it. [3]

In 2006, the total number of districts the in state of Jammu and Kashmir were raised to 22 after addition of eight new districts. Out of these 22 districts, 17 are Muslim majority districts. Out of these 17, 10 Muslim majority districts are in Kashmir and 06 are in Jammu whereas one is in Ladakh.

Out of the remaining five districts, four are in Jammu region that have Hindu population in majority. The remaining one is Leh and that remains the Buddhist majority district.

Although, at broader level across the state of Jammu and Kashmir, the population demographics were not majorly changed in past decade but looking into the special demographics of the human population in the state, communal terrorism has given a significant impact on it. [3]

As reported on the official website of Jammu and Kashmir government, Muslims currently constitute the 97 per cent of population in Kashmir Valley region of the state. 2\% of the population in the Kashmir Valley is of Hindus including majority of Megh Bhagats among them.

Table 1: Population and decadal growth rate by residence - Persons (Source: Ministry of External Affairs, Govt. of India) [10]

MILITANTS ACTIVITIES IN J\&K SINCE 1990 to 2001

\begin{tabular}{|c|c|c|c|c|c|c|c|c|c|c|c|c|c|}
\hline & 1990 & 1991 & 1992 & 1993 & 1994 & 1995 & 1996 & 1997 & 1998 & 1999 & 2000 & 2001 & $\begin{array}{l}\text { Since } \\
1990 \\
\text { upto } \\
\text { Dec.01 }\end{array}$ \\
\hline No. of Incidents & 4158 & 3765 & 4817 & 5247 & 5829 & 5938 & 5014 & 3420 & 2932 & 3071 & 3074 & 4522 & 5178 \\
\hline Civilians Killed & 461 & 382 & 634 & 747 & 820 & 1031 & 1336 & 948 & 857 & 821 & 762 & 919 & 9718 \\
\hline SFs Killed & 155 & 173 & 189 & 198 & 200 & 237 & 184 & 193 & 236 & 355 & 400 & 536 & 3053 \\
\hline Terrorists Killed & 550 & 844 & 819 & 1310 & 1596 & 1332 & 1209 & 1075 & 999 & 1082 & 1520 & 2020 & 14356 \\
\hline $\begin{array}{l}\text { Foreign Militants } \\
\text { Killed }\end{array}$ & 14 & 12 & 14 & 90 & 122 & 85 & 139 & 197 & 319 & 305 & 436 & 622 & 2358 \\
\hline
\end{tabular}


Hereby, the composition of the state's population at macro level is similar to that in 2011 Census - where Muslim to Hindu population ratio is nearly $2.4: 1$. But demographic equation at the micro level has changed during this period due to communal terrorism.
As per the figures released by state Directorate of Census Operations in a report published in 2013, Jammu and Kashmir faced a negative population growth by around six per cent in the decade from 2001 to 2011 .

Table 2: Population and decadal growth rate by residence - Persons (Source: Census of India 2011) [3]

\begin{tabular}{|c|c|c|c|c|c|c|c|}
\hline \multirow[t]{2}{*}{$\begin{array}{l}\text { District } \\
\text { Code }\end{array}$} & \multirow[t]{2}{*}{ State/District } & \multicolumn{3}{|c|}{$\begin{array}{c}\text { Population } \\
2011\end{array}$} & \multicolumn{3}{|c|}{$\begin{array}{c}\text { Percentage } \\
\text { Decadal Growth (Persons) } \\
\text { 2001-2011 }\end{array}$} \\
\hline & & Total & Rural & Urban & Total & Rural & Urban \\
\hline \multirow[t]{2}{*}{1} & 2 & 3 & 4 & 5 & 6 & 7 & 8 \\
\hline & Jammu \& Kashmir & 12548926 & 9134820 & 3414106 & 23.71 & 19.77 & 35.66 \\
\hline 01 & Kupwara & 875564 & 776322 & 99242 & 34.62 & 24.23 & 289.26 \\
\hline 02 & Badgam & 755331 & 666620 & 88711 & 24.40 & 24.23 & 25.67 \\
\hline 03 & Leh (Ladakh) & 147104 & 83901 & 63203 & 25.48 & -5.30 & 120.69 \\
\hline 04 & Kargil & 143388 & 130635 & 12753 & 20.18 & 20.23 & 19.67 \\
\hline 05 & Punch & 476820 & 438176 & 38644 & 27.97 & 25.68 & 61.16 \\
\hline 06 & Rajauri & 619266 & 575332 & 43934 & 28.14 & 27.96 & 30.54 \\
\hline 07 & Kathua & 615711 & 527176 & 88535 & 20.38 & 21.83 & 12.46 \\
\hline 08 & Baramula & 1015503 & 840948 & 174555 & 20.34 & 21.18 & 16.45 \\
\hline 09 & Bandipore & 385099 & 320070 & 65029 & 26.31 & 23.84 & 40.08 \\
\hline 10 & Srinagar & 1250173 & 15928 & 1234245 & 21.65 & -83.27 & 32.37 \\
\hline 11 & Ganderbal & 297003 & 250203 & 46800 & 36.30 & 22.54 & 241.08 \\
\hline 12 & Pulwama & 570060 & 491370 & 78690 & 29.18 & 27.62 & 39.87 \\
\hline 13 & Shupiyan & 265960 & 251010 & 14950 & 25.85 & 26.08 & 22.08 \\
\hline 14 & Anantnag & 1069749 & 791237 & 278512 & 37.43 & 25.80 & 86.36 \\
\hline 15 & Kulgam & 423181 & 343739 & 79442 & 7.40 & -8.36 & 320.06 \\
\hline 16 & Doda & 409576 & 377003 & 32573 & 27.89 & 26.33 & 49.17 \\
\hline 17 & Ramban & 283313 & 271527 & 11786 & 31.81 & 33.09 & 7.90 \\
\hline 18 & Kishtwar & 231037 & 216196 & 14841 & 21.06 & 22.90 & -0.64 \\
\hline 19 & Udhampur & 555357 & 445850 & 109507 & 20.86 & 22.79 & 13.63 \\
\hline 20 & Reasi & 314714 & 288010 & 26704 & 27.06 & 26.63 & 31.84 \\
\hline 21 & Jammu & 1526406 & 768577 & 757829 & 12.48 & 6.57 & 19.18 \\
\hline 22 & Samba & 318611 & 264990 & 53621 & 16.90 & 27.91 & -17.96 \\
\hline
\end{tabular}


Table 3: POPULATION GROWTH IN JAMMU AND KASHMIR, 1901-2011 ([2] Bilal 2018)

\begin{tabular}{|c|c|c|c|c|c|}
\hline \multirow{2}{*}{ Year } & \multirow{2}{*}{$\begin{array}{c}\text { Population } \\
\text { (in Lakhs) }\end{array}$} & Absolute Change (Lakhs) & \multicolumn{2}{|c|}{ Decadal Variation } & \multirow{2}{*}{$\begin{array}{c}\text { Average Annual } \\
\text { Growth Rate }\end{array}$} \\
\cline { 4 - 5 } & 21.39 &.-- & - & - & - \\
\hline 1901 & 1.53 & 7.16 & 5.75 & 0.69 \\
\hline 1911 & 22.92 & 1.31 & 5.75 & -0.31 & 0.56 \\
\hline 1921 & 24.24 & 2.45 & 10.14 & 11.0 & 0.97 \\
\hline 1931 & 26.70 & 2.76 & 10.36 & 14.22 & 0.99 \\
\hline 1941 & 29.46 & 3.07 & 10.42 & 13.31 & 1.00 \\
\hline 1951 & 32.53 & 3.07 & 9.44 & 21.64 & 0.91 \\
\hline 1961 & 35.60 & 10.55 & 29.65 & 24.80 & 2.63 \\
\hline 1971 & 46.16 & 13.70 & 29.69 & 24.66 & 2.63 \\
\hline 1981 & 59.87 & 17.31 & 28.92 & 23.86 & 2.57 \\
\hline $1991^{*}$ & 77.18 & 23.51 & 30.46 & 21.34 & 2.69 \\
\hline 2001 & 100.69 & 26.51 & 23.71 & 17.70 & 2.63 \\
\hline 2011 & 125.48 & Source: Various issues, Census of India, Jammu and Kashmir \\
\hline
\end{tabular}

*The 1991 census was not held in J\&K. The population of India includes projected population of J\&K (excludes area under occupation of Pakistan and China) as on 1.3.1991 made by the Standing Committee of Experts.

Percentage of total population living in villages has declined decade after decade. In fact, people from rural areas have migrated to urban areas because of security reasons, other facilities, and opportunities. ([2] Bilal Ahmad Khan 2018). Terrorism in the state has played decisional role in this migration.

\section{Conclusion}

Human Population in Jammu and Kashmir state of India comes consists of followers of Muslim, Hindu, Buddhist, and Sikh religion. Due to terrorism impacting the state for multiple decades, security has been a prime desire of residents. Communal terrorism has forced migration of non-Muslim population from Kashmir Valley to urban regions of Jammu. Uneven distribution of population has been governed by terrorism in the state for its current demography.

\section{References}

[1]. 6th Economic Census (2013), MOSPI (Department of Statistics), CSO, New Delhi.

[2]. Bilal Ahmad Khan (2018), "Demography of Jammu and Kashmir in Historical Perspective", Asian Review of Social Sciences, ISSN: 22496319 Vol.7 No.3, 2018, pp. 143-153,

URL: http://www.trp.org.in/wpcontent/uploads/2018/12/ARSS-Vol.7-No.3October-December-2018-pp.143-153.pdf, Retrieved 02 January 2019
[3]. Census of India (2011), "Population and decadal growth rate", URL: http://censusindia.gov.in/2011prov-

results/paper2/data_files/J\%20\&\%20K/Population $\% 20$ and\%20decadal\%20growth.pdf, Retrieved 02 January 2019

[4]. Eynul-din, H. K., Ahmadi, A., \& Ahmadi, S. (2015). Social and Economic Sustainability Analysis of Rural Settlements Located in the Hazard-Prone Areas: Case Study: Villages Surrounding the City of Sanandaj. IARS' International Research Journal, 5(2). Retrieved from

https://researth.iars.info/index.php/curie/article/vie w/52

[5]. Gera, N. (2013). Consequences of accelerated Global Warming on nature and economy and the remedies for Global Green Economy. IARS' International Research Journal, 3(1). Retrieved from

https://researth.iars.info/index.php/curie/article/vie $\mathrm{w} / 28$

[6]. India Today (2016), "Exodus of Kashmiri Pandits: What happened on January 19, 26 years ago?", URL: https://www.indiatoday.in/fyi/story/exodusof-kashmiri-pandits-january-19-jammu-andkashmir-304487-2016-01-19, Retrieved 12 December 2018 
[7]. Jammu and Kashmir Official Portal URL:

https://jk.gov.in/jammukashmir/?q=demographics, Retrieved on 01 January 2019.

[8]. JK Economic Survey (2017), Directorate of Statistics and Economics, Government of Jammu \& Kashmir, 2016-17.

[9]. Marcos Sanso-Navarro, Fernando Sanz-Gracia \& María Vera-Cabello (2019) The demographic impact of terrorism: evidence from municipalities in the Basque Country and Navarre, Regional Studies, 53:6, 838-848, DOI: 10.1080/00343404.2018.1490010

[10]. Ministry of External Affirs, Govt. of India (2002), "Fact Sheet on Jammu \& Kashmir", URL: https://mea.gov.in/in-focusarticle.htm?18987/Fact+Sheet+on+Jammu+amp+K ashmir, Retrieved 5 August 2018

[11]. Rosette, P. O. (2015). EFFECT OF GLOBAL RECESSION ON INDIAN REALTY SECTOR AND ITS FUTURE DEVELOPMENTS. IARS' International Research Journal, 5(2). Retrieved from https://researth.iars.info/index.php/curie/article/vie w/49

[12]. URL: https://brainly.in/question/6500317;

Retrieved 07 January 2019 